\author{
Alexandra Dantzer \\ Institut für Ethnologie, Westfälische-Wilhelms \\ Universität Münster, Deutschland \\ a_dant01@uni-muenster.de
}

\title{
Architects of happiness: Notes on the mindwork of migration
}

\begin{abstract}
The purpose of this paper is to propose an alternative take on the phenomena of migration by discussing the notion of happiness seen as technology of the self that is oriented towards the future and therefore connecting different times and places. This understanding is predicated upon the comprehension that happiness shapes what coheres as a world and that it is always anticipated, rather than actual. I want to argue that migration, instead as simple crossing of the border and settling for "better life", is an on-going mental process that I refer to as mindwork. Through the proposed framework mobility is understood as a way of achieving happy life. In contrast to previous theories, emotions are not seen as vehicles making the migration process easier or harder, but vice versa. By inverting the process anthropologist can refine their approaches in both fields, anthropology of emotions/happiness and migration studies and gain deeper insight into questions such as: what does it mean to be happy in a specific context, how does happiness enter the lives of people and last but not least why do some people migrate and what do they invest into this process marked with ambiguity?
\end{abstract}

Key words: migration, mindwork, cognitive migration, anthropology of happiness, emotions and migration

\section{Introduction}

When talking about migration it has become almost presupposed to think of them as derived from the attraction of different kinds of "push" and "pull" factors. When experiences of migrants are taken into account, one cannot avoid seeing that the process of mobility, time and again, leads to rupture and longing by those who leave, those who are left behind and those who return, and that is what I would further on refer to as migration contradictions (Gardner 2015). Having in mind these ambiguities one can ask, why migrate at the first place?

There is an emerging field of approaches considering the emotional implications of migration as a relatively new field, that are inextricably tied to the ambiguities of mobility, but the papers mostly tackle emotions in pathological 
and therapeutic terms, meaning that the potential of these approaches is not exploited to its fullest (Albrecht 2016). In this paper I am trying to propose a different approach towards migration and also answer to the previously stated question. The answer to myself lies in the notion of migration as a "happiness enterprise" (Gardner 2015), as a process that marks space and time and that never ends. The migration as a phenomenon is invested with an amount of hope that can be seen both, as a symbol, but also an enactment of itself and faith in the future, and finally as a reaction to hopelessness and loss at a present moment (Pine 2014). To begin with, some places are symbolically thought of as places of happiness and prosperity and those are the destinations towards which migrations are directed ${ }^{1}$ (Gardner 2015). Secondly, migrations are connecting the past, present and future, so that the migrants from the past serve as carriers of the knowledge of migration project, therefore as the ones establishing the migration routes. The future comes into play when the potential migrants, relaying on the migratory history known to them, project their potential happiness in space and in time prior and during the seek for their own prosperity. Migrations are journeys that are undertaken as an enterprise for pursuing happiness.

When looking at different narratives of actual migrants, it becomes clear that, relaying on the structural level of social life, one can distinguish different causes of migration. The palpable facts of living in the world marked by inequality cannot be rejected which was clearly shown in previous developments in the field of migration studies. Hence, the purpose of this paper is not to advocate disregarding these theories, more to supplement them with new lens to look at the lived experience of migrants. One cannot avoid mentioning structural problems that potential migrants are facing and these are extreme poverty, violence of war and conflicts, all the same structural violence on day-to-day basis. Humans reject the structures imposed onto them, by the act of migration in the project of a search for better life, which makes migration a political act in its essence. On the other hand, migrants are often faced with different types of exclusion and rejection in the host society, therefore are the narratives of people who migrate ripe with evidences of feeling excluded. Despite the fact that potential migrants are aware of migration contradictions, they, nevertheless, embark on a journey. When faced with structural violence in the country of origin, but also in the host

1 When talking about migration from richer countries to the ones that are economically disadvantaged the symbolical inscription of happiness is done out of different reasons than when migrations are having reversed routes. This is also why I believe the notion of happiness can broaden the view of migration in general, which will be clear in the further text. I have come across one of the papers dealing with migration from richer to poorer countries (Bartam 2015) and I believe that the findings are worthwhile mentioning in the light of possible shifts of perspective towards migration that could potentially enrich the field of migration studies. 
country, why do some people decide to migrate and others don't and what do they invest in the routes undertaken? I want to advocate an approach that would look at migration as a mindwork that is done even prior to migration, but also has to be re-done on day-to-day basis.

I would like to propose that migration is not only to be looked from a narrow perspective of "push" and "pull" factors, but rather as an enterprise, as an on-going emotional and mental process that is interconnected to ambiguity and contradiction. Despite these ambiguities, we see the enormous capacity of human agency, defiance and resistance in the process of making meaning of the world surrounding them. Due to the above stated state-of-arts in migration studies, my goal was to change my perspective and look at migration as happiness enterprises invested with hope, whereby happiness is understood as a highly culturally bound term. Furthermore, hope is understood as a complex notion resting on the capacity of imagination, sense of time/temporal progress and space. In the paper, further on, I will state the most influential theories on migration; secondly I will theorize about happiness as a concept and finally connect the two in a possible approach towards studying migration.

\section{On the phenomenon of migration}

In order to set the ground for further discussions and argumentations in the paper I will briefly underline the most important theories pertaining the phenomenon of migration. In doing so I am mostly relaying on the book written by Dragana Antonijević (Antonijević 2013), as this is one of the most detailed and comprehensive reviews of migration studies that I have until now come across, but also on couple of other sources.

After the Second World War international movement of people has become ever more complex and accelerated. Accordingly, it enhanced the formation of new motives and migration routes, which then lead to the creation of new forms of sociality and relations among different groups of people. This trend is ever increasing and it lead to the point where migrations are one of the most prevalent social forms in the present moment (Antonijević 2013). Migration is, generally speaking, temporary or permanent geographical movement of people out of different reasons. Migrations are old as humanity itself; however the migration studies are fairly new and therefore are taking into account mostly modern phenomena revolving around this term. Nevertheless, I believe that there is something in the nature of human beings making them want to move and relocate, and I would like to link it to cognitive processes and the role of imagination or mental stimulation that is a part of every journey undertaken by humans. I do not claim that there is something biologically universal to all of human beings 
and that this is the cause of migration, but I do believe that introducing the empirical concept of "cognitive migration" (Kyle and Koikkalainen 2011) linked to emotions and approach that would look at migration as imagining possible futures relaying on the knowledge pool that some groups of people hold in relation to being in the world, could enrich the understandings of migration as social phenomena.

During the 60ies the field of the studies of migration started to form itself in different academic disciplines and environments. In anthropology, the focus is on socio-cultural and value systems which are changing through the mobility of populations, on the cultural diffusion and inter-connections and on the creation of new identities (Antonijević 2013). Nevertheless, significant number of authors have, and still do, emphasize the necessity of an interdisciplinary approach that would merge different perspectives and theoretical and methodological frameworks, due to the fact that, in the present moment, the majority of works on migration are produced into the boundaries of single disciplines and are therefore studied partially (Antonijević 2013).

There are a couple of dominant theories of the migration phenomenon which I will briefly present in the following text. These theories can be categorized as micro, meso and macro theories of migration. Micro-level theories focus mostly on individual causes of migration and are mostly based on cost-benefit rational calculations, whereas macro-level theories look at aggregate migration trends and explain them from the macro-level perspective (Hagen-Zanker 2008). While both approaches tackle the causes of migration, in between there are meso-level theories that are mostly based on the community level, taking into account families and immediate surroundings of migrants and explain both causes and perpetuation of migration.

Regarding the rational choices to migrate which take into account personal losses and gains, the micro-approach of neoclassical economic theory was developed, which underlines individual choices driven by the possible economic gains. One of the examples is micro-approach based on human capital found in the work of Sjaastad (Sjaastad 1962) whereby the migration is seen as an individual investment decision taken in order to increase the productivity of human capital (Hagen-Zanker 2008) Furthermore, new economic theories put family in the focus of research, as the centre where the migration choices are met in order to minimize the risk and to lead towards economic benefits. For example, Bigsten (Bigsten 1988) considers migration a household decision in which a family allocates labour to the urban or rural sector depending on the marginal products of combined wages (Hagen-Zanker 2008). On the contrary there are macro-theories that relay on broader structural features of the modern globalized world. One of them is world system theory that emphasizes the relations of the centre (capitalistic West) and periphery, where the centre serves 
as a magnet for groups of people in search of better living conditions (Antonijević 2013). One of the most prominent examples is the world systems theory (Wallerstein 1974), which is derived from historical structural approach and therefore stresses the role of disruptions and dislocations in, what is considered, peripheral parts of the world, as a result of colonialism and the capitalist expansion of neoclassical governments and multinational companies (Hagen-Zanker 2008). The expansion of capitalism had profound effects on the world system, not only making the economic inequalities ever more profound, but also led to the transformation of cultures all over the world, development of stronger transportation connections and communication, which all led to the sublimation of the world we live in. The strength of this particular macro-approach stems in these facets when it comes to explaining the structural side of particular migrant routes established today.

All these theories are, to some extent or the other, dealing with the causes of migrations, but there are also the ones that are taking into account the socialization processes after migration, such as social networks theories and institutional theories. Relaying on the book on which this chapter is based I would state that the most prominent theories are the social network theories and transnationalism. Transnationalism is dealing with the double rootedness of migrants who are heavily bound to the places of origin and who live their lives between the borders, without having physically settled place of being.

\section{Anthropological perspectives on migration}

The first anthropological studies of migration also start in the 60ies, so that in the 70ies and 80ies migrations, in direct or indirect way, start to form the core of anthropological inquiry. The interests of anthropological inquiry are: who migrates and, moreover, why and how (Antonijević 2013). Furthermore, through ethnographic inquiry, which is in itself directed towards lived realities and the ways how these realities are constructed, negotiated and experienced, anthropology, with help of ethnography, tries to understand what it means to be a migrant and what are the values that migrants themselves attribute to their experiences, how they interpret and construct their identity (Antonijević 2013). Not long ago the focus started to shift towards gendered perspectives of migration and transnationalism which I have already mentioned above.

In thinking about interdisciplinary approaches towards migrations it is important to state that the advantage of anthropological micro-approach is that it looks the phenomenon from down to up, with the focus on individual and group experiences of migrants and their families. Due to the fact that anthropology, simply put, is a study of human beings it focuses on the lives of people, not so 
much on the structural societal changes, which only serve as a backdrop for contextualizing the subject of anthropological inquiry. The macro approaches offered us enough thinking material for contextualizing the phenomena we are dealing with, but our job is to find out what lies behind the notion of migration in terms of experience and emotions felt along the way.

Finally, one more crucial aspect of anthropological framework for studying migrations is the one focusing on the cultures of migrations, encapsulated in the study of symbols which reflect the crucial values regarding the process of migration (Antonijević 2013). Namely, when migrations start to be a permanent process in one specific area they, without any doubt, influence values and cultural perception increasing the possibilities for the further migrations to take place. (Antonijević 2013). This is what it is referred to as migration routes and creation of specific symbolic geographies with various values inscribed onto them.

\section{Happiness studies: General overview}

Action may not bring happiness, but there is no happiness without action

William James

The quote that I have used is just one of the overwhelming numbers of quotes about happiness that one could find, whereas happiness is of such central importance to the cultural context of ours. Happiness is constantly described as the object of human desire and the thing that gives purpose, order and meaning to our lives. Sara Ahmed, in her book that serves as a major source for this paper states that even Immanuel Kant, who has placed the individual happiness outside of the domain of ethics, argues that the propensity for happiness is the determining principle of rational beings' faculty of desire (Ahmed 2010). Furthermore, happiness as a topic is so elusive that it will, probably, always be debated about. It is, therefore, clear that a vast number of academics and thinkers offered their perspective on this topic. But what I believe is inextricably linked to the marvel of happiness is that the way how people conceive of happiness reveals which values they generally cherish. Accordingly, happiness is not a concept that could be thought of without presupposing the broader value system. Happiness is always "associated with some life-choices and others not" and it "is imagined as being what follows being a certain kind of being" (Ahmed 2010, 2). The history of the whole term is a history of different sort of associations and proclivities, so that in our wish to be happy we wish to be associated with happiness and therefore with all its associations.

In modern Western cultural context there is a shared belief that happiness is a private good, feeling which is a product of development and changing of ideas and conceptions of the goals of life in general and a way of being in the world, to 
put it phenomenologically. Notwithstanding, it is of crucial importance to keep in mind that even within our own intellectual heritage there are a vast number of understandings of the phenomenon. No matter how happiness is defined the notion of it always illuminates what is most desirable and worthwhile in person's life. For most people in the West happiness is about feeling good (Kitayama and Markus 2000) it is defined negatively, as absence of pain and suffering and it is connected to the ones' satisfaction with the life he/she has. In its essence, this notion is inherently subjective and the assessment of the life quality, affectively, but also cognitively, lies at its core.

At this particular moment in social sciences, but also at the level of policy making, we are facing the phenomenon called "happiness turn" (Ahmed 2010). Especially from 2005 and onward numerous books had been published in the field. (Layard 2006; McMahon 2006; Nettle 2006; Gilbert 2007; Schoch 2008 etc.) Besides, we face a rise in "happiness industry" embodied in different selfhelp programs and books, whereby happiness is both produced and consumed through them. One of the policy making measures is reflected in, now widely famous, move of Bhutan's government to measure a "Gross National Happiness" (Ahmed 2010,3) as a countermove to measuring the prosperity in strictly economical terms, but also, as a way of helping the development of policies that would raise the quality of people's lives. This move inspired the governments all around the globe and United Nations General Assembly declared the need that happiness should have a greater role in development policy. This move is however not a new idea, it is a core and crucial idea of a French Constitution and the US Declaration of Independence (Walker and Kavedžija 2015), founding document of United States, which says:

"We hold these truths to be self-evident, that all men are created equal, that they are endowed by their Creator with certain unalienable Rights, that among these are Life, Freedom and the pursuit of Happiness (...)"

(Declaration of Independence: A Transcript) ${ }^{2}$

In recent years, however, relaying on the above mentioned "happiness turn", psychologists and economists are putting a lot of effort in creating special and refined measuring instruments applied to the studies of happiness (Mathews and Izquierdo 2009). The methodology is however constructed mostly around questionnaires and surveys that would, more or less directly, enquire if people are happy and satisfied. The problem with these methods is, time and again, the Eurocentric notion of what happiness is and if it is at all possible to measure it so that it could be quantifiable. Besides these epistemological problems other problems are invoked and these are: Is happiness really the best and most de-

$2 \mathrm{https}: / / w w w . a r c h i v e s . g o v /$ founding-docs/declaration-transcript (accessed on 02.10 .2016 at $14: 55 h)$ 
sirable goal for all people? Why is maximizing happiness a more worthy goal than for example elevating capabilities and possibility for agency? (Walker and Kavedžija 2015). All these questions, but also the nature of the focus of attention towards happiness are the ones that are closely tied to the values of individualism and "post-neoliberal era" and capitalism in which the economy depends on emotional involvement and investment, but it is hard to sustain it due to the high percentages of inequality and alienation brought about with harsh individualism. Due to these facts stated above, happiness is the topic that urgently needs anthropological inquiry that is based on ethnographies of experience.

\section{The anthropological take on happiness}

Anthropology as a discipline mostly interested in common humanity amidst differences, but also inequalities, due to the critical approach that lies at its core, mostly deal with unhappy topics such as violence, pain, war and suffering. Besides that, happiness was seen as a bourgeois preoccupation that could be at odds with emancipatory politics (Walker and Kavedžija 2015). Sara Ahmed in her book Promise of Happiness (Ahmed 2010) critiques the notion moving through "the archives of happiness" which contain different sorts of text, visual and pop-cultural material. Through examining the Western notions of happiness, she is deconstructing the concepts of "affect alien" personified in three characters of "feminist killjoy", "unhappy queers" and "melancholy migrants" in her quest of picturing the notions of happiness as a form of social control. This book fits nicely into the preoccupations with inequalities of different kinds and, also, to the critical thinking axis of anthropology and it is also driven by an understanding that happiness is not a feeling, and especially not a subjective phenomenon, it is more of a construct highly bound to culture and power.

The debate about happiness is dominated by economists and psychologists, as I have already stated, and to avoid this debate among anthropologists could be a grave error. Namely, the ethnographic approach from bottom-up would be the way how anthropology could importantly contribute to the debates about happiness. The role of anthropologists in the debate would not be to offer comparative results on happiness levels, but to investigate how happiness figures as an idea, mood or driving force in people's day-to-day lives and how are the notions of happiness culturally shaped and conceptualized. In thinking about happiness one thinks about values of the context in question and necessarily connects them into a web of meanings that co-produce itself and that present, again, a way of being in the world. If we understand that "the study of happiness necessarily draws together considerations of meaning, values, and affect" (Walker and Kavedžija 2015,2) one can see that most ethnographic studies concerning ways and ends of different peoples life indirectly deal with the question 
of happiness. Finally, the feature that I see as the most important is that happiness is something that is never actual, or in the present moment, it is always seen as a "receding horizon", a pursuit that is always more virtual, than real and always out of ones' grasp (Walker and Kavedžija 2015, 3).

There is a difference made among cultural psychologists that are dividing the so-called communitarian and individualistic societies stating the differences in understanding of happiness (Ahuvia 2002). These approaches are useful in a sense that they practically show how happiness is connected to the broader understandings of sociality in general, but it is important to keep in mind that between these two poles lays a vast number of nuances and possibilities to be or not to be happy. Happiness is, as stated above, deeply connected to the values that are held dear, but it is not only differently conceived, but it is evaluated differently having in mind the circumstances. One more important thing is that happiness itself is about evaluation and assessment that is taking into account the whole social being of a person and the aims and goals of a human life that is deeply culturally specific. And finally, but most importantly, it can never be divorced from the spectrum of cultural values in connection to it.

Happiness is also deeply connected to the notions of well-being, and anthropology had its say in it, but anthropologists mostly focused on suffering and ill-being under the title of dealing with well-being, so they did not teach us a lot about what it means to be well in a specific culture. There is no doubt that these studies had given us significant knowledge about well-being, but time and again through referring to the dark sides of humanity and its suffering, so the information one can gather are indirect and therefore partial. Still, there are some works that started to part the way for more in-depth studies on well-being in anthropology and these are therefore worth mentioning (Corsin Jimenez 2007; Gough and McGregor 2007; Mathews and Izquierdo 2009).

Finally, the goal of anthropologists dealing with happiness is to question what happiness means to different people, does it even mean anything, but also how it is imagined and worked upon and how it enters the lives of people (Johnson et al. 2012). Happiness is shaped by cultural notions, but it also in return shapes them and can, moreover, trigger and activate different enterprises meaning that it triggers agency and actions. The ethnographic approach would be then the most useful one in grappling with the topic what it means to be happy in a specific time and place.

\section{Previous studies of emotion and migration}

In social sciences one can also spot a sort of "emotional turn" (Schützeichel 2006; Kleres 2009) that is now starting to enter the studies of migration. As a new and emerging field there is much space that was not addressed up until 
now, but the state-of-arts is so that the majority of works produced in the field focuses on pathological and therapeutic approaches towards emotions in general. The majority of papers are focused on depression and anxiety brought about with displacement from the country of origin fitting perfectly with the picture of "melancholic migrant" constructed in Sara Ahmeds' book (Ahmed 2010). The therapeutic part of the gaze is offering possible solutions in curing the neurotic and depressive migrant. The biggest problem with these approaches is that they subsume the category of migrants under an umbrella of passivity and further victimize them estranging them from their agency, and also the creative ways in which they interact with their environment, as the ill-being and negative emotions do carry negative connotations. Nonetheless, by "taking on an emotion-focused, non-pathological perspective it is possible to shed light on the general functions of emotions and their use in interactions during the process of migration" (Albrecht 2016, 26).

In her paper on emotions and migration, Yvone Albrecht gives a thorough list of previous studies and highlights the crucial studies done until now (Albrecht 2016). She highlights the term "emotion work" which she defines as a cognitive modification of the Hochschild's notion that "based on our feelings we develop our own view of the world" (Hochschild 1983, 41). The term "emotion work" is directly and indirectly encompassed in the studies concerning care and sustaining of family ties across distance (e.g. Baldassar 2007; Ryan 2008; Maehara 2010; Lau 2010). These works are mostly focused on the topics of separation and loss and difficulties in maintaining intimacy between kin. In these studies the substrate is researching in which ways are family ties re-forged and sustained in a transnational context, the focus is on the concept of reciprocity, care and even guilt for leaving people behind. Still, all of these studies do not tackle the questions how emotions are culturally constructed and ingrained into the core of migration as a process; emotions are seen only as a vehicle to hold the family across borders. In the same vain there are papers dealing with the geographies of caring from a gendered perspective focusing on migrant mothers going to work as care-givers to first world children and leaving their children behind. These papers are usually filled with narratives of sorrow and loss, but also do not interrogate which emotions are at stake and what they mean (Hochschild 2002).

One of the studies that creatively uses the term "emotion work" is a study of a Swedish sociologist Mona Linqvist (Linqvist 2013) and it is concerned with the coping mechanisms of the integration process using the work of emotions (Albrecht 2016). Linqvist is referring to something she coins "foreign habitus" drawing from Bourdieu, which migrants adopt in order to create and sustain their "migrant self". According to the author this creation of migrant identity is crucial in maintaining the notion of difference and inner self. The participants in the study were all women from different countries and they all reported in 
which way they work their emotions in the process of integration. Some things seem problematic in these analysis, first that the author chose exclusively women in order to study a topic such as emotions, because it perfectly fits into the dichotomy of female $=$ emotional: male $=$ rational. Furthermore, the paper deals with the ways of learning to express emotions in new context that is restrictive to openly expressing them. Again, we do not learn about what it means to feel certain emotions in one context or the other, as the emotions are only seen as expressions that have to be culturally fitting, but not as facts that are directly molded by culture, because we do not only learn how to express things, we also learn how to feel them. This paper has two major strengths and these are highlighting that the process of integration does not mean only learning the language and rules of the society and secondly that the process of migration is an emotion work per se.

One of the papers, that I would like to mention, is dealing with emotion work among African refugees in Sweden, whereby the author detects this process on two levels. First as a way of investing into hope that the status of the individuals would increase over time and, on the other hand, as a way of preserving self-dignity in the process of asylum application (Wettergren 2015). She distinguishes surface and deep acting in the process of emotion-work, where the surface acting is defined in Goffman's terms of performing the role of a good migrant compliant with the rules of the host country he has entered. The point of deep acting is the one that I found more provoking, as the author presents the internal struggles of refugees and their emotional responses to a situation that denies them dignity and the way how loss of self-respect is internalized and worked upon. Through snippets of presented ethnography we learn how differently individuals cope with the same situation, as the author gives examples of individuals feeling out of place and uncomfortable in their new surroundings, and on the other hand how some of them reject the notion that they are confronted with racist behaviour and reject to internalize the exclusion. The part of presented ethnography which deals with deep emotional work of people who have migrated is the one that I consider thought provoking and that gives more insight in how emotions are negotiated and adjusted in a situation of discontinuity that migration brings. Still, I feel that the experience of distress is accentuated as the emotions as cultural constructs are not in the focus of the paper. The theoretical framework of emotions as coping mechanisms is employed which again does not leave enough space to discuss emotions as crucial part of the migration journey that connect different times and spaces and could be a driving force to migrate at the first place.

Finally, I want to mention the studies focusing on nostalgia and feeling of loss after the migration takes place. These studies are also concerning feelings of loss and longing stemming from emotional terms. Howbeit, nostalgia is here 
only taken as a framework to speak about topics as identity and return migration and the studies are again on the side of ill-being.

The gaps that I have noticed in the works familiar to me, and that I have tried to address with what will follow is the fact that emotions are tackled from a strict country of origin: host country dichotomy. Moreover, they look at emotions only as vehicles of integration, family sustaining or creation of migrant identity. I do believe that putting emotions at the centre of the studies of migration could bridge the gap between localities of different kind and cross-cut the spatial boundaries assumed in studies of mobility, as I believe, even from my own experience of migrating that in these processes there is never a clear cut of being here and there. One is at the same time at both places before, during and after migrating and the mindwork done in the whole process is crucial in making meaning of the experience of migration.

\section{Happiness and migration}

Migration to another country is a process undoubtedly invested with great deal of hope and this hope is not only connected to economic gains and the will for increased social status. Seeing migration in this way does not leave us enough room to investigate the different causes and ways in which people migrate. Migration could be understood as an experience of biographical discontinuity, which does not, by default, have to be traumatic and involve crises (Albrecht 2016). Migrants are not only passive sufferers of conditions of migration, therefore they have to be brought back into the narratives of migration as they are the subjects of it, which is not so often done when the emotional aspects of migration are invoked. By doing this "it is possible to recognize the actors and narrators as individuals who shape transition themselves instead of constructing them as executors of cultural logic or victims of their presumed conflict" (Breckner 2005, 56).

Happiness as a concept and apprehension, due to the qualities that I was mentioning above is a term that is offering more possibilities in thinking of migration processes. First of all, the economic gains are not a sure thing even among migrants coming from poorer to wealthier countries, not to mention the migrations vice versa. Secondly, the social status is almost always decreased after the migration took place. Finally, the economic gains are not a key to happier life, so in that way not a crucial motivator to undergo such a radical change as migration is.

I would like to argue that migration, rather as a simple crossing of the borders and settling for the "better life" process, is an on-going mental process which I refer to as mindwork. I see the interplay of migrations and happiness in such a way that migrations are the possible way of imagining happier future. 
In that way happiness is seen as technology of the individual that is oriented towards the future making happiness sort of a project per se. As I have already mentioned, happiness shapes the worldview, and it is always rather foreseen than definite (Ahmed 2010). The migrations could, then, be seen as journeys undertaken as quests for happiness (Gardner 2015). Rather than seeing spaces towards which migrations are leading, as places of economic prosperity, and therefore a "pull" factor, we have to take into account that these places are symbolically ascribed with values of happiness and success through already established migrant routes. This is how the mindwork of migration, even prior to actual migrating, connects places and spaces in reality divided by boarders in one moment in a time. The symbolical geography, triggered by life stories of migrants shared with the ones that stayed, is crucial at the point of imagining possible futures. Human brains were made for nexting, meaning anticipating, and people are "blissfully unaware that (their) nexting brain is predicting a future...at a fantastic rate" (Gilbert, 2007, 7). In this mindwork there is a tendency towards imagining futures and a practice of ascribing happiness in a route that serve as a trigger for action. In migration studies there is a tendency to focus on the outcomes of migration and exploration of the topics of integration, economic activity, social status, nostalgia, identity construction, return migration etc. These approaches see migration as a process of crossing the border physically and permanently, even when the ties with the homeland are still perpetuated, and therefore as a phenomenon fixed in time and space, which can lead towards returning if the nostalgic feelings are overwhelming. An orientation towards migration as a happiness project would focus the researchers to look beyond these established notions of what migration is.

Migration is a process that starts a lot earlier than it takes actual place. The ethnographic studies of migration would be even more enriched if the focus could be turned towards studying in which way cognitive migration, meaning "the narrative imagining of oneself inhabiting a foreign destination prior to the actual physical move, influences migration behaviour" (Koikkalainen and Kyle $2016,1)$. The process of deciding to migrate is followed by cognitive migration meaning that the individual visualizes itself and projects itself into the future and different place. While doing so one is negotiating its own possible social world and its emotional states. Potential migrants engage in cognitive migration (Kyle and Koikkalainen 2011) as they start to imagine themselves socially, but also emotionally in a different space and time in future. Therefore, the minds of people still settled at one place start to migrate even before the move has taken place and this decision to do so is based on a deeply social dimension as the world we know it offers us a menu of possible choices in our decisions on how to live life. The mindwork is crucial because "by engaging in mental time travel into our own possible futures we work out the highly complex emotional and social implications of that decision" (Kyle and Koikkalainen 2011, 8). This is how 
migration marks space and time, but also connects different spatial/temporal levels at one single point in time. Having this in mind it is clear that migration is an open-ended process connecting past, but not only individuals' lived past, more the past of the social circle in which the individual is habituated, present and future.

I believe that the connecting point between migration and happiness is that both are dynamical and moving phenomena. Preceding is also physically moving, but from what I have written above it requires mental movement in a form of imagination which is ever evolving. This type of trans-local and trans-temporal imagination is not exclusively embedded in the migrants, it is a mental process happening also among stayers, and I would like to argue that migration can be exclusively mental, without the need to physically cross the border. This virtual migration could be an anthropological topic to deal with (Kyle and Koikkalainen 2011). Happiness also requires the mindwork in which the values and notions are inscribed. What it means to be happy and how is the happiness achieved are the crucial things to consider when dealing with migration. There are at least three related things indicated with the term happiness and these are emotional happiness, moral happiness and judgmental happiness (Gilbert 2007). The first one is directly linked to the feeling of happiness, which is not of concern for this paper. The latter two are the forms of happiness related to what I am trying to propose with the connection of studying migration and happiness in the same framework. Moral happiness is the one that is always connected to the virtue of living a good life in terms of what is acceptable in one context or another. For example, nowadays happiness is considered as something coming from inside and something that is connected to the individual choices and steps taken in life. On the other hand, in Ancient Greece happiness was conceived to be a product of virtuous performance of ones' duties towards the society. It was believed that happiness should not be measured until the death of the person when his/hers' life as a sum is a measure of happiness and virtues collected during the life span. The third concept is the most important one for this paper. This concept is referring to the expression of beliefs in merits of certain things and happenings. It is, so to speak, analytical happiness. The judgmental happiness or happiness about is the one that includes thinking about what it is that it is supposed to make one happy and it can be rationalized and planned. The combination of the latter two types of happiness from this categorization which is, as every categorization, flawed but it serves more as a thinking map and simplification mechanism, are the ones whose framework should be filled with ethnographic content in order to search for the answers on questions what is positively and what negatively assessed in one context and in the other. To put it simply what is seen as worth. Through the concept of happiness, understood in this way, different cultural values can be highlighted and by doing that the process of migration could be even 
more elucidated on the micro-level of ethnography from bottom-up. Through this framework migration are seen as now already cultural value and a means towards achieving happy life. This is achieved through the building of different symbolical systems and creation of shared history of mobility among different social groups. Even when leading to rupture and longing migrations are still undertaken and the question of what and out of which reasons is invested in these journeys is the one that leads us to think about why it is believed that movement is needed.

\section{Conclusion and discussion}

In this paper my goal was to propose a framework for an alternative take on migration, but also present the work relevant to the particular framework. The trigger in thinking about the problem in this light was the fact that although migrations are desired and seen as a path to better and more prosperous life, the migrants and movers, but also the ones left behind face more ambiguous reality, or even better realities. The goal of using such a framework would then be gauging the ways in which contradictions play out over peoples' lives and destinies and the way in which the happiness project is then cognitively, but also physically, worked upon. By looking at migration as a quest for happiness and as a mindwork, the attention is shifted from the goal-orientated approach, which leads to answers of success and un-success, towards emotional implications of planning and undergoing through the process of migration (Gardner 2015). Having in mind the spatial/temporal divisions and values ascribed to some times and some places, the notion of happiness not as measurable emotion, but more as "a wish, a will, a want" (Ahmed 2010,2) highlights the complexities of the decision-making process and cultural values and notions ascribed to it. This symbolical inscription of values can help us connect different places and times and discuss these connections, rather than differentiate between what is called a host society and society of origin. In that way, the migration as the way of being in the world is seen as a dialectical process. Migration as happiness project, as I see it, would rely on the notion that cognitive and physical movement is "a question of following, rather than finding" (Ahmed 2010, 32). In this light the research on migration starts to be more open-ended and complex, which leads to more nuanced views and understandings. No matter which aspect is taken into account, be it creation of social-networks or the decision-making processes, research of emotional aspects of migration do fit well within the framework.

I would like to conclude this paper with possible problems with this approach and open up a place for discussion on it. First and foremost, when taking this framework onto the practical fieldwork the problem of how to evaluate emo- 
tions reported by the study informants is evinced. This problem is equally actual when talking about present and past emotions, exactly due to the mindwork and cognitive mapping that takes place in the process of framing a coherent mindset. Another problem directly tied to the previous one is what is meant by the term of happiness, and which is discussed at length for centuries now among academics, philosophers and lay people (Annas 1995). It is a problem that immediately follows when anthropology starts to deal with emotions, due to the more or less intrinsic nature of it. That is why anthropological inquiry about happiness is not able to offer a comparative approach on what happiness means in the vast thinking horizons and answer to the questions such as: are some people happier than the others? But what anthropology can do is answering the question what it means to be happy to different groups of people and what these people do to make their lives happier.

\section{References}

Ahuvia C., Aaron. 2002. Individualism/Collectivism and Cultures of Happiness: A Theoretical Conjecture on the Relationship between Consumption, Culture and Subjective Well-Being at the National Level. Journal of Happiness Studies 3: 23-36.

Albrecht, Yvonne. 2016. Emotions in Motion. How feelings are considered in the scope of migration sociological studies. Digithum 18: 25-33.

Annas, Julia. 1995. The Morality of Happiness. Oxford University Press. Oxford.

Antonijević, Dragana. 2013. Stranac ovde, stranac tamo: Antropološko istraživanje kulturnog identiteta gastarbajtera. Beograd: Srpski genealoški centar.

Ahmed, Sara. 2010. The Promisse of Hapiness. Durham NC: Duke University Press.

Baldassar, Loretta. 2007. Transnational families and the provision of moral and emotional support: The relationship between truth and distance. Identities. Global Studies in Culture and Power 14 (4): 385-41.

Bartam, David. 2015. Inverting the Logic of Economic Migration: Happiness among Migrants Moving from Wealthier to Poorer Countries in Europe. Journal of Happiness Studies 16 (5): 1211-1230.

Bigsten, Arne. 1988. A Note on the Modelling of Circular Smallholder Migration. Economics Letters 28: 87-91.

Breckner, Roswitha. 2005. Migrationserfahrung - Fremdheit-Biografie: Zum Umgang mit polarisierten Welten in Ost-WestEuropa. VS Verlag: Wiesbaden.

Corsin-Jimenez, Alberto. 2007. Culture and Well-Being: Anthropological Approaches to Freedom and Political Ethics. Pluto Press. Michigan

Gardner, Katy 2015. The path to happiness? Prosperity, suffering and transnational migration in Britain and Sylhet. HAU: Journal of Ethnographic Theory 5 (3): 197-214.

Gilbert, Daniel 2007. Stumbling on Happiness. New York: Random House, Inc., Vintage Books

Gough, Ian and Allister McGregor. 2007. Wellbeing in Developing Countries: From Theory to Research. Cambridge University Press. Cambridge 
Hochschild, Arlie Russel. 1983. Das gekaufte Herz: Die Kommerzialisierung der Gefühle. University of California Press. Berkley/Los Angeles.

---. 2002. "Love and Gold”. In Global Woman. Nannies, Maids, and Sex Workers in the New Economy, Barbara Ehrenreich and Arlie Russell Hochschild (eds.), 34-46. A Holt Paperback. New York.

Hagen-Zanker, Jessica. 2008. Why do people migrate? A review of the theoretical literature. https://mpra.ub.uni-muenchen.de/28197/. Accessed: 28.12.2016.

Kleres, Jochen. 2009. "Preface: Notes on the Sociology of Emotions in Europe". In Debra Theorizing Emotions: Sociological Explorations and Applications, Hopkins et al. (ed.), 7-29. Campus Velag. Frankfurt/ Main.

Koikkalainen, Saara and David Kyle. 2016. Imagining mobility: the prospective cognition question in migration research. Journal of Ethnic and Migration Studies 42 (5): 759-776.

Kyle, David and Saara Koikkalainen. 2011. Cognitive Migration: The Role of Mental Stimulation in the (Hot) Cultural Cognition of Migration Decisions. Paper is a part of the Decision Making for a Social World web conference organized by the International Cognition and Culture Institute and The Philosophy, Politics and Economics Program, University of Pennsylvania. January.

Lau, Timm. 2010. The Hindi Film's Romance and Tibetan Notions of Harmony: Emotional Attachments and Personal Identity in the Tibetan Diaspora in India. Journal of Ethnic and Migration Studies 36 (6): 967-987.

Layard, Richard. 2006. Happiness: Lessons from a New Science. Penguin Books. London. Lindqvist, Mona. 2013. 'Like a white crow': Migrant women and their emotion work in Sweden. International Journal Work Organisation and Emotion 5 (3): 229-242.

Maehara, Naoko. 2010. Emotional Ambiguity: Japanese Migrant Women in Mixed Families and their Life Transition. Journal of Ethnic and Migration Studies 36 (6): 953-966.

Markus, Hazel Rose and Shinobu Kitayama 2010. Cultures and Selves: A Cycle of Mutual Constitution. Perspectives on Psychological Science 5 (4): 420-430.

Mathews, Gordon and Carolina Izquierdo 2009. Pursuits of Happiness: Well-being in Anthropological Perspective. New York: Berghan Books.

McMahon M., Darrin. 2006. Happiness: A History. Atlantic Monthly Press. New York. Nettle, Daniel. 2006. Happiness: The Science behind Your Smile. Oxford University Press. Oxford.

Pine, Frances 2014. Migration as Hope: Space, Time, and Imagining the Future. Current Anthropology 55 (S9): 95-104.

Ryan, Louise. 2008. Navigating the emotional terrain of families "here" and "there": Women, migration and the management of emotions. Journal of Intercultural Studies 29 (3): 299-314.

Schoch, Richard. 2008. The Secret of Happiness: Three Thousand Years of Searching for the Good Life. Scribner. New York.

Schützeichel, Rainer (ed.). 2006. Emotionen und Sozialtheorie: Disziplinäre Ansätze. Capmus. Frankfurt/New York.

Sjaastad, Larry. 1962. The Costs and Returns of Human Migration. Journal of Political Economy 70 (5): 80-93.

Wallerstein, Immanuel. 1974. The Modern World System. Academic Press. New York. 
Walker, Harry and Iza Kavedžija. 2015. Values of Happiness. HAU: Journal of Ethnographic Theory 5(3): 1-23.

Wettergren, Ása. 2013. "Protecting the Self against Shame and Humiliation: Unwanted Migrants' Emotional Careers”. In: Die Ambivalenz der Gefühle: Über die verbindende und widersprüchliche Sozialität von Emotionen, Kleres, Jochen/ Albrecht, Yvonne (eds.), 221-224. VS Verlag. Wiesbaden.

\section{Sources:}

https://www.archives.gov/founding-docs/declaration-transcript (accessed on 02.10.2016 at $14: 55 \mathrm{~h})$

Alexandra Dantzer Institut za etnologiju, Univerzitet u Minsteru, Nemačka

\section{Dizajneri sreće: Zapisi o misaonom procesu migracija}

Cilj ovog rada je izlaganje alternativnog pristupa migracijama kroz promišljanje pojma sreće, shvaćenog kao tehnologija sopstva koja je orijentisana ka budućnosti, a koja samim tim povezuje različite prostorne i vremenske horizonte. Ovakvo razmevanje pojma je zasnovano na shavtanju da sreća oblikuje koherentni svetonazor i da je osećanje sreće uvek očekivano, pre nego trenutno. $\mathrm{U}$ radu je argumentovano da migracije predstavljaju neprekidan misaoni proces koji nazivam mindwork, pre nego prost prelazak nacionalnih granica u potrazi za „boljim životom“. Na osnovu predloženog teoretskog okvira migracije su shvaćene kao jedan od puteva ka srećnom životu. Za razliku od prethondih radova koji se tiču odnosa emocija i migracija, u radu emocije nisu shvaćene kao sredstvo koje iskustvo migracije čini lakšim ili težim, već vice versa. Preokretanjem perspektive antropolozima je omogućeno da oplemene pristupe u oba polja, antropologiji sreće/emocija i migracija i da odgovore na pitanja kao što su: šta znači biti srećan u određenom kontekstu, kako pojam sreće figurira u svakodnevici ljudi i poslednje, ali ne najmanje bitno, zašto ljudi migriraju i šta ulažu u procesu koji je obeležen ambivalentošću kao što su migracije?

Ključne reči: migracije, mindwork, kognitivne migracije, antropologija sreće, emocije i migracije

\section{Designers du bonheur: Écrits sur le processus réflexif des migrations}

L'objectif de ce travail est d'exposer une approche alternative des migrations à travers la réflexion sur la notion du bonheur; comprise comme technologie de soi orientée vers le futur, et qui par conséquent relie différents horizons spatiaux 
et temporels. Une telle appréhension de la notion est basée sur l'idée que le bonheur façonne une vision du monde cohérente et que le sentiment du bonheur est toujours attendu plutôt que momentané. Ici est soutenue la thèse que les migrations représentent un processus réflexif ininterrompu que j'appelle mindwork, avant de représenter un simple passage des frontières nationales à la recherche d'une „meilleure vie“. À partir du cadre théorique proposé, les migrations sont comprises comme un des chemins vers une vie heureuse. À la différence des travaux précédents qui concernent le rapport des émotions et des migrations, ici les émotions ne sont pas comprises comme un moyen rendant l'expérience de la migration plus facile ou plus difficile, mais c'est justement l'inverse. Par le renversement de la perspective les anthropologues ont la possibilité d'ennoblir les approches dans les deux champs, celui de l'anthropologie du bonheur et des émotions et celui de l'anthropologie des migrations et de répondre à des questions telles que: que signifie d'être heureux dans le contexte précis; comment la notion du bonheur figure dans le quotidien des hommes et en dernier lieu, mais non moins important, pourquoi les gens migrent et ce qu'ils investissent dans un processus marqué par l'ambivalence comme l'est celui des migrations?

Mots clés: migrations, mindwork, migrations cognitives, anthropologie du bonheur, émotions et migrations

Primljeno / Received: 13.12.2016.

Prihvaćeno / Accepted: 4.02.2017. 